\title{
Interactions in Non-English Major Large Classes in Vietnam
}

\author{
Trần Thị Thanh Thương ${ }^{1} \&$ Lê Phạm Hoài Hương ${ }^{2}$ \\ ${ }^{1}$ College of Foreign Economic Relations, Ho Chi Minh city, Vietnam \\ ${ }^{2}$ College of Foreign Languages, Hue University, Vietnam \\ Correspondence: Lê Phạm Hoài Hương, English Department, College of Foreign Languages, Hue University, \\ Vietnam. E-mail: quangandhuong@gmail.com
}

Received: November 8, 2016 Accepted: December 2, 2016 Online Published: January 19, 2017

doi:10.5539/ijel.v7n2p106 URL: http://dx.doi.org/10.5539/ijel.v7n2p106

\begin{abstract}
This study examines interactions in non-English major large classes in Vietnam. Audio recordings of classes of economics and business were used for data analysis. The study adopted sociocultural discourse analysis (Mercer, 2004) which focuses on the use of language as a social mode of thinking and a tool for teaching-and-learning, constructing knowledge, creating joint understanding and tackling problems collaboratively. The findings show that teachers mediated learners with their prompts, questions and scaffolding. Interactions between teachers and students assisted students in understanding and building concepts related to their majors, learning English language expressions and vocabulary.
\end{abstract}

Keywords: classroom interactions, sociocultural theory, non-English major large classes

\section{Introduction}

\subsection{Interactions in Sociocultural Theory}

Sociocultural theory was developed by Vygotsky and his colleagues (Lantolf, 2000). According to sociocultural theory, the individual and the social were "conceived of as mutually constitutive elements of a single interacting system" (Cole, 1985, p. 148) and that one's cognitive development is socially and culturally created. In this sense, sociocultural theory emphasizes classroom interactions since "through socially mediated activities and the eventual individual(s)-acting-with-mediational means, the social and individual planes of human psychological activity are interwoven" (Lantolf, 2000, p. 258).

According to Ellis (2000), sociocultural theory assumes that learning arises not through interactions but in interactions. Learners first succeed in performing a new task with the help of another person and then internalise this task so that they can perform it on their own. Gibbons (2003) point out that teachers, through their interactions with students, mediate between the students' current linguistic levels in English and their commonsense understandings of science, on the one hand, and the educational discourse and specialist understandings of the subject, on the other.

A key concept of sociocultural theory is scaffolding proposed initially by Wood, Bruner, \& Ross (1976). According to Donato (1994) scaffolding is a concept that derives from cognitive psychology and L1 research. It states that in a social interaction, a knowledgeable participant can create by means of speech and supportive conditions in which the student (novice) can participate in and extend current skills and knowledge to a high level of competence. In an educational context, however, scaffolding is an instructional structure whereby the teacher models the desired learning strategy or task then gradually shifts responsibility to the students. McKenzie (1999) stated that scaffolding provides the following advantages: a) It provides clear directions for students b) It clarifies purpose of the task c) It keeps students on task d) It offers assessment to clarify expectations e) It points students to worthy sources, and f) It reduces uncertainty, surprise and disappointment.

\subsection{Previous Studies on Classroom Interactions}

Studies using sociocultural theory as a conceptual framework have focused on the roles of language, both the target language and the mother tongue in mediating students' learning. Anton (1999) investigated learner-centered and teacher-centered discourse in interactive exchanges between teachers and learners in the second language classroom. The finding shows that in discourses where learners were centered, they could negotiate form, content, and rules of behaviors. In comparison, teacher-centered discourse provided rare opportunities for negotiation. The 
author concluded that when learners were engaged in negotiation, language was used to serve the functions of scaffolding.

In Tognini's (2007) study, the researcher investigated the interaction of teachers and learners in ten primary and secondary school languages other than English (LOTE) classes in Western Australia, with the aim of providing a detailed picture of its nature and patterns. The study found that teacher-learner interaction featured various types of negative feedback, positive evidence and considerable reliance on interactional routines such as elicitation, non-corrective repetition, drilling and reinforcement.

Meanwhile Larkin (2007) and Spiro (2011) focused on interactions in online classrooms. Larkin (2007) determined the techniques instructors used to interact in an online environment and what procedural interaction criteria the instructors considered effective without face-to-face interaction. Spiro (2011) determined how interaction was facilitated in an online instructional media course and investigated the value that instructors and students placed on interaction in an online course.

Le (2007) examined student interaction in two group settings, "unassisted" and "assisted." The first consisted of five students from the same class and the second of four from the same class and a more knowledgeable student from a higher class. The findings show that the senior student made a marked difference to the organization of the assisted group's processes in starting their discussions, explained new English words, and increased the use of English in this group setting.

The study by Gibbons (2003) focused on how teacher-student talk in a content-based (science) classroom contributes to learners' language development. The findings indicate that teachers, through their interactions with students, mediate between the students' current linguistic levels in English and their commonsense understandings of science, on the one hand, and the educational discourse and specialist understandings of the subject, on the other.

Swain, Brooks, \& Tocalli-Beller (2002) pointed out that collaborative dialogue is beneficial in language learning because when learners encounter linguistic problems, the dialogue can help them to solve the problems together. In such conditions language is used both as a communicative and cognitive tool.

In general, previous studies on sociocultural theory and classroom interactions have examined different aspects of interactions such as scaffolding, collaborative talk, the roles of peers in learning, interactional routines, and teacher-student negotiation. There remains an issue to be explored, which is the patterns of classroom interactions in non-English major large classes in a specific context and how interactions between teachers and students and among students lead to classroom learning in terms of concepts both for a specific major and English.

\section{Method}

\subsection{Audio Recordings}

In this study, 45 lesson periods of different non-English major large classes were audio recorded. Each class had 50 students or more majoring in business or economics. The classroom teachers and students were asked for consent for the recordings. Besides, the teachers were advised that the class should be taught in the way that it happened normally. The randomly chosen classes were from several universities in Vietnam. All of the audio recordings were then transcribed by the researchers and analyzed using sociocultural discourse analysis (Mercer, 2004, p. 141).

\subsection{Sociocultural Discourse Analysis}

According to Mercer (2004), sociocultural discourse analysis focuses on the use of language as a social mode of thinking and a tool for teaching-and-learning, constructing knowledge, creating joint understanding and tackling problems collaboratively. In this study, transcriptions of classroom interactions were selected as excerpts/extracts of transcribed talk to which the analysts provides a commentary. The interaction is treated as a form of intellectual activity and as a social mode of thinking. It incorporates a concern with the lexical content and the cohesive structure of talk, especially across the contributions of individual speakers, because word choices and cohesive patterning can represent ways that knowledge is being jointly constructed. The transcriptions show talking turns of teachers and students. Where Vietnamese is used, translation is provided in square brackets.

\section{Results}

The following excerpt illustrates how both the target language and the mother tongue helped students to grasp a concept of "joining a department" in a business class. 


\section{Excerpt 1: Classroom interaction for concept understanding}

Teacher: Các bạn xem cô Stephany cô nói nè [Listen to Ms. Stephany everyone], "I'm joining”, rồi sau cái từ joing là gì ạ [What is the phrases used after "joining"?] Marketing department—là cái bộ phận hay là nghề nghiệp? [Is this a department or a job?] Là một vị trí công việc hay là 1 bộ phận nào? [A job or a department?]

Students: A position.

Teacher: Nói mãi mà chúng ta vẫn chưa nhớ là sau “joining” thì phải dùng cái gì ạ? [I have reminded you for many times but you don't remember what words should be used after joining]

Students: Human resources.

Teacher: Human resources là cái gì? [What is it?]

Students: Bộ phận. [A department]

Teacher: Bộ phận [A department]. Good. Như vậy muốn dùng joining thì phải nói là gì ạ? [So, if you want to use "joining", how should you say?]

Students: Human resources department.

The teacher was trying to elicit the correct answers for "joining a department" or "human resource department" from students. The interaction went on with several responses until the students could make the correct answers from their understanding. In this excerpt, students answered in chorus. It could happen for the reason that the class was crowded and the collective response was a norm or it could be influenced by the characteristic of Vietnamese collective culture. Besides, the teachers asked the question openly to all the students. The teacher's speech mediated students and assisted them to correctly understand a business concept and a language expression.

In the excerpt below, the teacher asked students to talk about their ideal manager, a topic in their lesson for economics.

\section{Excerpt 2: Classroom interaction for concept building}

Teacher: Now, in five minutes you who have imagine who is your ideal manager. The question is, what is your ideal manager like? Are they male or female? What qualities do you think he/she should have? Now, 5 minutes to prepare. Now, who volunteers to tell me what is your ideal manager like? Who volunteers? Oh, you please!

Student 1: My ideal manager is male. First, He's an ambitious person and he has the ability to manage the staff, control his feeling well and solve problems. He's also a careful person. He must treat his staff fairly and have good thinking, always prepares for each change of the company. He must be decisive and confident in everything. He should have a good communication skill and responsibility to what he does....

Teacher: Good. Very good. Thank you. Another person? Volunteer? Now, you please!

Student 2: I think a male is the manager because he deals with problems quickly and he has a good mind, creative, so it makes the staff impressive...

Teacher: OK. Thank you. Another person. In your opinion, what is your ideal manager? You please!

Student 3: First, an ideal manager in my mind is very handsome, he's about 25-35 and he's very funny. I think he's smart, strong knowledge and strong relationship. He must have ambitions, he can listen to all suggestions from staff, and believe in his employees' ability. He's active and enthusiastic in his work to motivate his staff.

Teacher: Very good. Your idea is very good. Another person? You please!

Student 4: My ideal manager is a handsome person and he's dynamic and decisive, listens to others and is responsible to what he does...

Teacher: What else? That's all? OK. Thank you. I will ask a boy. You please!

Student 5: My ideal manager is a person who is creative and decisive and has responsibility for the job....uhm...

Teacher: How old is he?

Student 5: Not important.

Teacher: It's not important for you? OK. I will ask you a question. A manager needs to be handsome?

Students: Yes.

Teacher: You please! Yes or no? 
Student 6: Yes.

Teacher: Why?

Student 6: Because if the manager is handsome, I would have motivation to work.

Teacher: OK. If the manager is handsome, the staff will love him and devote all the experience to work. How about you? Your ideal manager?

Student 7: My ideal manager is female.

Teacher: Female? OK.

Student 7: Yes, because I think female is more considerate than male managers. And male managers have hot temper.

Teacher: Hot temper? OK. Does female have hot temper or male?

Student 8: Male.

Teacher: Male is often hot-tempered.

Student 8: Yes, and I and my female manager can talk together.

Teacher: OK, good. What else?

Student 7: And she's going to use flexible policy. That's all.

Teacher: Good. Do you think than male has possible policy or female has possible policy?

Students: *discussing*

Teacher: In your opinion, male or female?

Students: Female.

The students in this extract collectively built up their interaction responding to the topic of an ideal manager. They were able to use the target language to develop their ideas and each student tried to have a different opinion. The qualities and image of an ideal manager at the end of the excerpt seems to be very critical. Apparently, the questions from the teacher in this excerpt such as "What else?", "How old...?", "Yes or no?" or "How about you?" "In your opinion...?" as well as opinions given by different students led to various responses of the whole group. English was used as a social mode of thinking and interaction between the teacher and students constructs knowledge of the lesson among students.

In excerpt 3 below, students were discussing movements of price.

\section{Excerpt 3: Classroom interaction for learning language expressions and lesson content}

Teacher: Now, any volunteers?

Student 1: Em đọc 1 câu, bạn đọc 1 câu được không cô? [Can I read the first sentence and my friend reads another?]

Teacher: uhm.

Student 1: Let's look back the moment at how the dollar has performed against the Euro over the last 6 months.

Teacher: Very good. The first one is over the last 6 months. "Over" means you use before the time but the period of time. Next!

Student 2: It stayed steady for the first month of the year at around 1 point, uhm, of 0.93 Euro to 1 dollar in February however, its value fell by 2 points from 0.93 to 0.91 Euro.

Teacher: Very good. Now we have "fell by". Và vì nó giảm cho nên nó có cái movement [As it fell, there was a movement] Các bạn thấy ở đây movement là nó từ 0.93 ha, nó có sự chuyển đổi từ \$0.93 lên tới 1 Euro. [You see, the movement here is from 0.93 because there was a change from $\$ 0.93$ to 1 Euro].

Student 1: In the second half of February, the dollar rose to almost 96 Euro ... remained stable for the first half of March.

Teacher: OK. Bạn nói là "In the first" đúng không? Hay là "during”? [Did you say "In the first" or "during”?]

Student 1: In

Teacher: À, ngoài ra chữ "In" chúng ta còn sử dụng được chữ "during" nữa. Tại vì "the second half" là nó cũng vừa có thể tính là 1 điểm thời gian ha các bạn, trong cái 6 tháng cuối năm đúng không? Hoặc là trong khoảng 6 
tháng cuối năm, cho nên chúng ta có thể sử dụng được 2 chữ ở đâylà "in" và "during" ha các bạn. [Bedise the word "in", we can use "during" because "the second half" can be a period of time and for the last 6 months, so we can use both "in" and "during" in this context.]

Student 2: uhm, during the next 6 weeks, it rose to almost 10 point to 0.86 Euro. It then increased again slowly in May and June.

Teacher: Very good. Ở đây May and June chúng ta vẫn có thể sử dụng được during các bạn, tại vì May and June có thể là 1 khoảng thời gian. [Here, we can use "during" for May and June because they refer to a period of time"

Some students: On

Teacher: On, đúng không? Ví dụ như on Monday, on 15 September chẳng hạn, ngày 15/9 chẳnghạn. [On, is it correct? For example, on Monday, on 15 Sept]

Student 3: Thưa cô là went up là có rose. [Teacher, "Went up" as the meaning of "rose"]

Teacher: Very good.

Student 3: and increase.

Teacher: Increase. OK.

Student 3: uhm, went down là có drop, [went down means drop]

Teacher: Yes.

Student 3: uhm, fell.

Teacher: Good.

Student 3: uhm, no movement là có stay steady, remain stable. [If there was no movement, we can use stay steady or remain stable].

Teacher: Very good.

In this excerpt, students were learning the concept of movements in prices, they also had an opportunity to review synonyms, for examples, go up and rise, fall and decrease, etc. They reviewed the prepositions to use with time expressions. Clearly, such classroom interactions provided students with language input and opportunity to produce output related to the content of the lesson. It cannot be denied that the explanations from the teacher consolidated the target language among the students.

In excerpt 4 below, the teacher was asking the students to match the words in an email with definitions which come from a task in the course book.

\section{Excerpt 4: Classroom interaction for language elicitation and appropriate use}

Teacher: Bây giờ các bạn có những chữ in nghiêng ở trong này nè, các bạn thấy không? Các bạn thấy những chữ in nghiêng người ta bảo là match the words in italic in the email to the definition from 1-5. [Can you see the italic words in the book? You are asked to match the words in italic in the email with the definitions from 1-5] What are the definitions called?

Students: Items.

Teacher: Items. Very good. Rồi thứ 2 là [Second] is example of things to show customers. Hàng mẫu, hoặc là các thứ mẫu để các bạn đưa cho khách hàng xem, thì gọi là gì? [What do you call the samples to show customers?]

Students: Sample

Teacher: Sample. Rồi cái thứ 3 là shop with the same name and sell the same things, là gì? [Third, what do you call the shops with the same name and sells the same things?] những cái cửa hàng mà cùng tên ha các bạn, ví dụ như các bạn có là lotteria, các bạn thấy ở Lotteria quận 1, Lotteria quận 10, Lotteria quận Tân Bình thì cái đó gọi là gì? [The shops such as Lotteria in districts 1, and 10 and Tan Binh District. What do you call them?]

Students: Chain.

Teacher: Yes, a chain a shop. How about people that work in these shops?

Students: Staff

Teacher: Staff, very good. Choice of items, a lot of them. What do you call them?

Students: Range. 
Teacher: Yes, range. Ok, number 3, use "would" and "could" to make your requests more polite. For example, say "I want to ... this item." How do you say in a polite way?

Students: I would.

Teacher: Very good. I would like. Number 2, send me your brochure and price list. To be polite, how would you say?

The teacher was relating to examples in real life to help students understand the concept of a chain of shops, more specifically, the chain of Lotteria shops in Ho Chi Minh City. The questions put by the teacher facilitated students to give the answers in English despite the fact that he/she used the mother tongue. The class was responding collectively, using the words in English to refer to the business concepts. In this excerpt, the students also learned how to use language politely in English. The class was a community of language users practicing shared knowledge.

In excerpt 5 below, the students were discussing a business plan. The problem was raised by the teacher on how students should prepare for a business plan.

\section{Excerpt 5: Class interaction for problem solving and concept understanding}

Teacher: For example, you want to set up a company, so, how far ahead should you prepare for the business plan? Who wants to give me the answer?

Students: [Discussing]

Teacher: That means how much time it is necessary for you to set up the plan.

Student 1: I think it takes about 3 years.

Teacher: About 3 years?

Student 1: Yes.

Teacher: Why do you need 3 years?

Student 1: Because I need the budget. I need the resources and experience, and I need the place to open a company.

Teacher: The location. You need to have the time to choose the location, right?

Student 1: Yes.

Teacher: OK, thanks! Everybody, she said that she needs about 3 years, a 3-year time for her to plan the business, or to set up a business. Do you agree with her? She said that she needs time to prepare for the capital or the budget, and she also need time to choose the location and the products. And, how about you, everybody? Do you think that it is a short time for you or you need less time than that?

Students: *discussing*

Student 2: I think the business plan should be 6 months, because it's not a long time, so if anything happens, you don't have to change too much plan.

Teacher: OK, others, everybody. So everybody, do you think that maybe 3 years is too long?

Students: Yes.

Teacher: For example, you want to set up, you want to open a coffee shop. And you think that maybe there are few coffee shops around this college, so you intent to set up a coffee shop over there. And if you think of opening a coffee shop over there, you have to go there and to deposit for hiring a building or the house.... Now I think you just mention something about applying for a license, you know the word "license"?

Students: Bằng lái...[Driving license]

Teacher: Giấy phép kinh doanh chứ không phải bằng lái, kinh doanh mà xin bằng lái chi...! [A business permit, not a driving license].

Students: *laughing*discussing*

Teacher: Đúng không các bạn? Thời gian các bạn xin giấy phép nè, thời gian các bạn lắp cái facility mình muốn làm nè, những cái đó các bạn phải đầu tư, đầu tư vốn liếng, đầu tư kinh nghiệm... [Is that correct? You need time to ask for a business permit, installing facilities for your business, time to invest capital and experience]

Students: [Continue discussing] 
[The teacher then played the CD for students to listen]

Clearly, the students did not satisfactorily solve the problem as they did not reach the conclusion. However, during the course of interaction, they had an opportunity to listen to ideas from other students as well as to give their opinions. Again, in this excerpt, the teacher helped students to differentiate the word "driving license" and "business permit". Knowledge of the concept and language use were built through the talk between the teacher and students.

In the following excerpt, the teacher was asking students to do a vocabulary task from the course book.

\section{Excerpt 6: Classroom interaction for English vocabulary learning}

Teacher: Now, do exercise 1: Vocabulary matching. You match the opposite as in the example. Now look at the example: reliable, the opposite is unreliable, right! What is the opposite of upmarket?

Student 1: Down market

Teacher: Yes, down market.

Class: *discussing*

Teacher: Discounted, right! Yes or no?

Students: *saying something*

Teacher: Value for money. Full price. And last one, high standard of service - poor service. Now repeat after me please! The whole class. High quality.

Students: High quality.

Teacher: Low quality.

Students: Low quality.

Teacher: Upmarket.

Students: Upmarket.

Teacher: Downmarket.

Students: Downmarket

Teacher: Reliable

Students: Reliable

Teacher: Unreliable

Students: Unreliable

Teacher: Well-made

Students: Well-made

Teacher: Badly made

Student: Badly made

Teacher: Overpriced

Students: Overpriced

Teacher: Value for money

Students: Value for money

Teacher: Full price

Students: Full price

Teacher: Discounted price

Students: Discounted price

Teacher: High standard of service

Students: High standard of service

Teacher: Poor service

Students: Poor service 
Teacher: Bây giờ cô sẽ đọc 1 từ, các bạn đọc từ trái nghĩa cho cô nha. Cả lớp cùng đọc. Upmarket. [Now, I say a word, you all will give an opposite word. In chorus please].

Students: Downmarket.

Teacher: Full price

Students: Discounted price.

Teacher: Again!

Students: Discounted price.

Teacher: Good. Well-made

Students: Badly made.

Teacher: Reliable.

Students: Unreliable.

Teacher: Overpriced

Students: Value for money.

Teacher: High standard of service

Students: Poor service.

Teacher: Discounted price.

Students: Full price.

Teacher: Again!

The speech produced by students repeated what was given in the course book but such interaction between the teacher and repetition by students seemed to help students to learn the words. They were able to promptly give the antonyms of the specialized words. It remains a question whether students will remember the words or not and be able to use them but the classroom interaction indicates that they understood and used the words at that time.

\section{Discussion}

\subsection{Teachers-Students Interaction}

All the excerpts above demonstrate that through interaction with each other, teachers and students constructed a common body of knowledge (Hall \& Walsh, 2002). Clearly, as the interactions take place within instructional contexts, they are elicited by teachers (Ralston, 2004). Besides, the patterns of the excerpts above featured various types of feedback, positive evidence and considerable reliance on interactional routines such as elicitation, non-corrective repetition, drilling and reinforcement as pointed out by Tognini (2007). Besides, all the excerpts in this study show features of reciprocal interaction between teachers and students which were carried out through the use of prompting questions such as "why?", "what else?", "how about ..?" or unfinished sentences by the teacher.

The findings reiterate the dominant patterns of classroom interactions which include a three-part sequential IRE (Information, Response, Evaluation) exchange (Sinclair \& Coulthard, 1975). This exchange involves the teacher, in the role of expert, eliciting information (I) from individual students in order to ascertain whether each student understands the task. The teacher does this by asking a known-answer question to which the student is expected to provide a brief response (R). The teacher then evaluates the student's response (E) with such typical phrases as "Good," "That's right", or "No, that's not right." Clearly, the teachers in this study are used to such interaction patterns of IRE. As Johnson (1995) pointed out that the patterns of communication in most classrooms are not explicitly taught, but they are implicitly enforced through teachers' use of language. In addition, the patterns of interactions in this study indicate that teachers usually posed questions which come from the textbooks or elaborated questions from the textbooks. To respond to teachers' prompts, students gave answers, then feedback such as "right" "ok", "good". The teachers in the excerpts played the roles of an expert or a gatekeeper. In other words, the excerpts show scaffolding between teachers and students. In most cases, the teachers also provided temporary help with vocabulary and expressions in both English and Vietnamese, which "assists learners to move toward new skills, concepts, or levels of understanding" (Gibbons, 2002, p. 10). In addition, the transcripts of classroom interactions in this study demonstrate that in non-English major large classes in Veitnam, pair work and group work were employed to provide opportunities for students to interact as found in the study by Tran \& 
Le's (2013). These authors revealed that the majority of the teachers in their study reported to adopt teamwork, group work and pair work as strategies to make students more responsible and active in their study in large classes.

Anton (1999) investigates learner-centered and teacher-centered discourse in interactive exchanges between teachers and learners in the second language (L2) classroom. The analysis of interaction shows that learner-centered discourse provides opportunities for negotiation (of form, content, and classroom rules of behavior), which creates an environment favorable to L2 learning. The current study shows that teachers -students interaction with scaffolding questions from the teachers to help students understand their lessons.

From the recordings, it is argued that the patterns of classroom interactions in non-English major large classes in Vietnam are somehow determined by the tasks provided in the course book. All the excerpts indicate that teachers usually asked students to work on a given task in the course book. Teachers then monitored, facilitated, controlled, managed and reinforced students on the task. It remains unknown what the teacher-students interactions would be if there were no task requirements given.

\subsection{Interactions as Reciprocal Knowledge Construction}

Sociocultural approaches (Lantolf, 2000) emphasize the interdependence of social and individual processes in the co-construction of knowledge. Knowledge can be some concepts in a field of study, certain vocabulary or things that learners have not known or have known and want to share. The extracted excerpts give evidence of the collective sharing of linguistic knowledge and specialized knowledge. For examples, students shared and co-constructed their understanding of joining a department, a chain of shops, a business plan (excerpts 1, 4 and 5), qualities of good manager (excerpt 2), prepositions to follow certain verbs (excerpt 6). It cannot be confirmed whether all the students in the excerpt have already known the concepts/words or not, but it is apparent that classroom interactions gave them opportunities to collectively share understanding.

The finding of the current study reiterates the study by Gibbons (2003) that teachers, through their interactions with students, mediate between the students' current linguistic levels in English and their commonsense understandings of a subject/major (in this study: business and economics), on the one hand, and the educational discourse and specialist understandings of the subject, on the other.

Sociocultural theory indicates that through repeated participation in interaction activities with more capable members, we acquire the linguistic, sociocultural and other knowledge and competencies considered essential to full participation (Leont'ev \& James, 1981; Vygotsky, 1981). The more opportunities for taking part in our activities, the more fully we develop the linguistic, social and cognitive knowledge and skills needed for competent engagement. Besides, through interactions, the "expert" can scaffold or mediate others' learning (Lantolf, 2000). Clearly, the teachers in all the excerpts above played the role of the expert giving guidance to students and helped them solve the problems from the course book. Teachers provided necessary vocabulary and language expressions so that students could continue with the course of thinking and complete the tasks given.

\subsection{The Use of the First Language in Classroom Interactions}

In all excerpts, except for excerpts 2 and 6 , the first language was used. The teachers used the first language to explain task requirements, to manage the class, to explain new words, to monitor group work, to explain business concepts. Thanks to teachers' use of the first language, students were able to proceed with their tasks and understand the concepts. The fact that they were able to continue their interactions with the teachers and other students indicates that the first language assisted them and mediated their thinking process. Thanks to the first language, they could use and complete the tasks in the target language. The students also relied on the first language in similar ways employed by teachers. However, the students in this study did not use the first language to manage the class or give instructions as their roles were to complete the tasks.

The recordings of classroom interactions reiterate the findings by Le \& McDonald (2004) that the first language was used by Vietnamese students of English to negotiate task planning and procedure, to share understanding, and to help each other with unfamiliar English words. The current study's findings also confirm that students rely on their mother tongue when they cannot engage in meaningful interaction in the foreign language (Polio \& Duff, 1994). Clearly, the first language provides an effective way of getting to grips with what needs to be done in the second language (Nation, 2003). According to Antón \& DiCamilla (1998), L1 use is found to serve a critical function in students' attempts to mutually define various elements of their task. Also, L1 is shown to be an indispensable device for students in providing each other with scaffolded help (Wood, Bruner, \& Ross, 1976). This study provides evidence of the use of L1 for the purpose of externalizing one's inner speech (Vygotsky, 1986) throughout the task as a means of regulating one's own mental activity. 
This paper provides a number of excerpts showing interactions in non-English major large classes. It does not show all aspects of interactions in such contexts. In general, in non-English major large classes at the research site, L1 was used rather frequently. The teachers usually adopted the roles of experts, managers, facilitators and mediators in classroom interactions. Although the use of English did not occur much as expected, students were able to understand and build concepts of their majors of business and economics thanks to the mediation of speech (in both L1 and English) by the teachers and other students. However, the question of whether students will be able to use their understanding and knowledge for future use remains a question for further study.

\section{References}

Anton, M. (1999). The discourse of a learner-centered classroom: Sociocultural perspectives on teacher-learner interaction in the Second-Language classroom. The Modern Language Journal, 83(3), 303-318. http://dx.doi.org/10.1111/0026-7902.00024

Antón, M., \& DiCamilla, F. (1998). Socio-cognitive functions of L1 collaborative interaction in the L2 classroom. Canadian Modern Language Review, 54(3), 314-342. http://dx.doi.org/10.3138/cmlr.54.3.314

Cole, M. (1985). The zone of proximal development: Where culture and cognition create each other. In J. Wertsch (Ed.), Culture, communication, and cognition: Vygotskian perspectives (pp. 146-161). Cambridge, UK: Cambridge University Press.

Donato, R., (1994). Collective scaffolding in second language learning. In J. P. Lantolf (Ed.), Vygotskian approaches to second language research (pp. 33-56). London: Ablex Publishing.

Ellis, R. (2000). Task-based research and language pedagogy. Language Teaching Research, 4(3), 193-220. http://dx.doi.org/10.1177/136216880000400302

Gibbons, P. (2003). Mediating language learning: Teacher interactions with ESL students in a content-based classroom. Tesol Quarterly, 37(2), 247-273. http://dx.doi.org/10.2307/3588504

Hall, J. K., \& Walsh, M. (2002). 10. Teacher-student interaction and language learning. Annual Review of Applied Linguistics, 22, 186-203. https://doi.org/10.1017/S0267190502000107

Johnson, K. E. (1995). Understanding Communication in Second Language Classrooms. N.Y.: Cambridge University Press.

Lantolf, J. P. (2000). Introducing sociocultural theory. Sociocultural theory and second language learning, 1-26.

Larkin, C. A. (2007). Instructional Techniques for online interaction in higher education. A dissertation submitted to the Faculty of the Graduate School Texas A\&M University- Commerce in partial fulfillment of the requirements for the degree of Doctor of Education.

Le, P. H. H.(2007). The more knowledgeable peer, target language use, and group participation. Canadian Modern Language Review, 64(2), 329-350. http://dx.doi.org/10.3138/cmlr.64.2.329

Le, P. H. H. , \& McDonald, G. (2004). Mediation through the first language: A sociocultural study of group work in Vietnam. New Zealand Studies in Applied Linguistics, 10(1), 31-49.

Leont'ev, A. A., \& James, C. V. (1981). Psychology and the language learning process. Pergamon.

McKenzie, J. (1999). Scaffolding for success. The Educational Technology Journal, 9(4), 12.

Mercer, N. (2004). Sociocultural discourse analysis. Journal of Applied Linguistics, 1(2), 137-168. https://doi.org/10.1558/japl.2004.1.2.137

Nation, P. (2003). The role of the first language in foreign language learning. Asian EFL Journal, 5(2), 1-8.

Polio, C. G., \& Duff, P. A. (1994). Teachers' language use in university foreign language classrooms: A qualitative analysis of English and target language alternation. The Modern Language Journal, 78(3), 313-326. http://dx.doi.org/10.1111/j.1540-4781.1994.tb02045.x

Sinclair, J. M., \& Coulthard, M. (1975). Towards an analysis of discourse (p. 246). New York: Oxford.

Spiro, D. (2011). Examining Instructor and Student Perspectives of Online Interaction. An Applied Dissertation Submitted to the Fischler School of Education and Human Services in Partial Fulfillment of the Requirements for the Degree of Doctor of Education. Nova Southeastern University.

Swain, M., Brooks, L., \& Tocalli-Beller, A. (2002). 9. Peer-peer dialogue as a means of second language learning. Annual Review of Applied Linguistics, 22, 171-185. https://doi.org/10.1017/S0267190502000090

Tognini, R. (2007). Interaction in languages other than English classes in Western Australian primary and 
secondary schools: theory, practice and perceptions. A thesis submitted in fulfillment of the requirements of Doctor of Philosophy (Applied linguistics), Faculty of Education and Arts School of International, Cultural and Community Studies.

Tran, T. T. T., \& Le, P. H. H. (2013). Managing strategies in teaching English in large classes at College of Economics, Hue University. Journal of Science, 88(10).

Vygotsky, L. S. (1986). Thought and language (rev. ed.).

Wood, D., Bruner, J. S., \& Ross, G. (1976). The role of tutoring in problem solving. Journal of Child Psychology And Psychiatry, 17(2), 89-100. https://doi.org/10.1111/j.1469-7610.1976.tb00381.x

\section{Copyrights}

Copyright for this article is retained by the author(s), with first publication rights granted to the journal.

This is an open-access article distributed under the terms and conditions of the Creative Commons Attribution license (http://creativecommons.org/licenses/by/4.0/). 